\title{
Students Who Strip: The Benefits of Alternate Identities for Managing Stigma
}

\author{
Mary Nell Trautner \\ University at Buffalo, State University of New York \\ Jessica L. Collett \\ University of Notre Dame
}

\begin{abstract}
We apply interactionist theories that highlight the contextual nature of stigma and the relational quality of stigmatization to the case of college students who work as topless dancers. We explore how the "toll of stripping" might be mediated by having an alternate, positive identity like "student." Our analysis demonstrates that students who strip are distinctive from other strippers in important ways that stem from their salient, positive identity as students. Although they often feel as if they live a "double life" because they hide their occupation from family and friends, they benefit from sharing their student goals and ambitions with club customers. "Student" is a socially acceptable identity to share in routine social interactions and helps student strippers frame dancing as a transient occupation, offering them an opportunity to maintain a positive sense of self while buffering them from some of the negative effects of stripping.

Keywords: stigma, sex work, stripping, interaction, deviance
\end{abstract}

Goffman's treatise Stigma: Notes on the Management of a Spoiled Identity (1963) fundamentally transformed how scholars conceptualize and study deviance, marginality, and stigma. In our view, one of the most promising lines of inquiry that continues to thrive today is the contextual or situational nature of stigma (Crocker 1999; Crocker and Quinn 2001) and a focus on the relational quality of the stigmatizing process (Jones et al. 1984). This research elucidates the power that individuals have over their own and others' perceptions of stigmatizing or deviant traits, and helps explain the contradictory effects of stigma on self-esteem (Crocker and Quinn 2001). Despite sociology's strengths in attending to contexts, situations, and relationships, the bulk of the research exploring these processes has largely been conducted

Direct all correspondence to Mary Nell Trautner, Department of Sociology, University at Buffalo, SUNY, Buffalo, NY 14260; e-mail: trautner@buffalo.edu.

Symbolic Interaction, Vol. 33, Issue 2, pp. 257-279, ISSN 0195-6086, electronic ISSN 1533-8665. (C) 2010 by the Society for the Study of Symbolic Interaction. All rights reserved. Please direct all requests for permission to photocopy or reproduce article content through the University of California Press's Rights and Permissions website, at http://www.ucpressjournals.com/reprintinfo.asp. DOI: 10.1525/si.2010.33.2.257. 
by psychologists working in laboratories (Hebl and Dovidio 2005). In this article we draw on in-depth interviews to attend to this oversight and open the door to a more sociological, and interactionist, study of the construction and management of deviant and stigmatized identities, both internally and interpersonally.

Goffman (1963) highlighted three types of stigma: "abnormalities of the body" (i.e., physical abnormalities or deformities), "tribal identities" (i.e., membership in discredited or oppressed groups), and "blemishes of individual character" (i.e., behavior that deviates from a moral standard). Research suggests that individuals in the first two categories are able to protect their self-image and often possess equal or higher levels of self-esteem compared with the unstigmatized (Crocker and Major 1989). Findings on self-image among those in the last category, with signs of a flawed character, are more mixed. For instance, research on obesity, which many believe to be the result of individual action (or inaction) rather than uncontrollable physiology (Crandall 1994), suggests that obesity is one of the most debilitating stigmas (Allon 1982). However, Crocker (1999; Quinn and Crocker 1999) finds significant variation among overweight women and suggests obesity's negative effect on self-esteem varies with an individual's perception of control. Here we follow Crocker (1999; Crocker and Quinn 2001; Quinn and Crocker 1999) and explore potential buffers against the negative effects of character stigmas. Specifically, we ask how possessing an alternate, positive identity might buffer an individual from potential negative effects of another deviant or stigmatized identity, by examining how students who strip actively engage their identities as students to protect and enhance their views of self, both internally and in interaction with others.

The literature is replete with accounts of the negative consequences of stripping for young women, what Barton $(2006,2007)$ refers to as the "toll of stripping." Women who work in strip clubs battle intense stigmatization from society, face verbal and physical harassment and abuse from managers and customers (Wesely 2006), and compromise their relationships and sense of self to work in an occupation that ultimately alienates them from others and from themselves (Barton 2007). Research suggests, largely as a result of these pressures, that stripping negatively affects dancers' self-concepts and self-esteem (Wesely 2003), inhibits them from forming or maintaining intimate relationships with others (Philaretou 2006), and often leads to other deviant and dangerous behaviors including prostitution and drug and alcohol abuse (Salutin 1977). The majority of this literature (and indeed on deviant identities in general) theorizes on the assumption that the deviant identity is the only salient identity an individual has and that possessing this devalued identity is causally related to low self-esteem (Allport 1954). Here we question this assumption and consider how the toll of stripping may be mediated by simultaneously holding an alternative, positive identity.

We find a number of ways that students who strip are distinctive from other strippers, including possessing a resiliency against stigmatization, which we argue stems directly from the opportunity to draw on the alternative identity of student. After a brief review of the contextual nature of stigma and research on how individuals negotiate and manage deviant identities, we turn to a more-focused discussion of the 
literature on strippers and strip clubs. We then introduce our data and methodological approach, and discuss our findings and their implications for studies of identity and interaction. We conclude by returning to the current state of research on stigma and suggest directions for future research.

\section{THE CONTEXTUAL NATURE OF STIGMA: STRIPPERS AND STIGMA MANAGEMENT}

We focus on the most characteristically “deviant” of Goffman's (1963) types of stigma-blemishes of individual character. Strippers are generally deemed deviant as they engage in "a perceived behavior or condition that is thought to involve an undesirable departure ... from a putative standard" (Archer 1985:748). Because they are paid for this behavior, stripping becomes a type of "dirty work" (Hughes 1951) that can threaten a stripper's sense of self. Much of the research on strippers has found that internalized negative perceptions can result in many negative outcomes for dancers including lower self-esteem (Barton 2006), relationship dissatisfaction (Downs, James, and Cowan 2006), and emotional instability (Peretti and O'Connor 1989). These deleterious consequences are expected from early work on stigma and labeling (Allport 1954; Goffman 1963). Later research, however (see reviews by Crocker and Major 1989 and Major and O'Brien 2005), suggests that these effects are not necessarily uniform.

The effect of stigma on an individual's well-being greatly depends on context as well as the individual's actions. Self-esteem is "constructed at the moment, in the situation, as a function of the meanings that individuals bring with them to the situation" (Crocker and Quinn 2001). That is, we are not passive recipients of others' perceptions of us but active participants in constructing our selves (Cooley 1902; Mead 1934). The stigmatization process is relational, dynamic, and complex. How people cope with stigma significantly influences the effects of that spoiled identity (Miller and Major 2000).

Research suggests that a potential mediating factor in the negative implications of stigmatization for self-esteem is the centrality of a deviant identity to one's selfconcept (Major and O'Brien 2005). The more an individual identifies with a particular identity - that is, the more salient it is - the more likely that person is to perceive negative interpersonal outcomes (e.g., devaluation or stereotyping) as related to that identity, and the more lasting and deep the negative effects (Branscombe, Schmitt, and Harvey 1999). It follows, then, that possessing additional positive identities might offer individuals an alternative to adopt as their central, or defining, identity-a way to disengage from the stigmatizing social identity (Schmader et al.2001). In this sense, one's self can expand and contract (Brewer 1991) across contexts and situations. We argue that student strippers can use this malleability to maintain, and even enhance, their positive sense of self.

A number of studies on strippers (often implicitly) distinguish between "career" dancers and "transient" dancers (Philaretou 2006; Sweet and Tewksbury 2000a). 
Career strippers "tend to adhere to their dancing careers as an end in itself" (Philaretou 2006:47), or, as Ronai and Cross (1998) put it, they are "immersed" dancers, who view stripping as a permanent, full-time job. These women tend to be less educated and skilled, and have few alternatives to earning the living that stripping provides (Ronai and Ellis 1989; Salutin 1977; Sweet and Tewksbury 2000b; Thompson and Harred 1992). Women who view their stripping as more of a temporary occupation, on the other hand, tend to be more educated and skilled (Sloan and Wahab 2004). With a variety of opportunities available to them outside dancing, these women approach their work in the clubs as a transitory way to achieve more lofty career or personal goals. Thus they tend not to become immersed in the work and the lifestyle.

There are no systematic data on the qualities of strippers over time; however, some research suggests that strippers are generally more educated today than they were in the past (Bradley 2008; Reid, Epstein, and Benson 1995; Sweet and Tewksbury 2000b). This may suggest an increase in transient strippers who have other opportunities and view stripping as a more temporary endeavor that fits with their current situation or future ambitions. It may also suggest a transformation of topless clubs in general. Since the 1970s, strip clubs have spread beyond so-called red light districts to suburbs and other areas outside city cores. This transformation of the industry led to the growth of elite, upscale bars, what Bradley-Engen (2009) calls "show clubs," that cater to middle-class and business clientele, as well as to a more diverse group of dancers in terms of their social class, education, and lifestyles.

Studies of the deviance of stripping are a primary line of research on strippers and strip clubs (Frank 2007). These studies tend to focus on how women come to enter a deviant occupation, patterns of interaction between customers and dancers, and how women manage the stigma associated with stripping for a living (Lewis 2000). Like much of the literature on other types of stigma, techniques of neutralization (Sykes and Matza 1957) and information control (Goffman 1963) form the basis for much of the discussions of the stigma management strategies employed by women who strip. Most studies show that strippers are aware of the stigma associated with stripping and thus use both internal and interpersonal strategies to rationalize, to redefine, or to justify the occupation or their participation in it (Ronai and Cross 1998; Ronai and Ellis 1989; Salutin 1977; Scott 1996; Skipper and McCaghy 1978; Thompson and Harred 1992; Thompson, Harred, and Burks 2003).

A number of studies show how women redefine the occupation in an attempt to remove the stigma associated with stripping. Women in Ronai and Ellis's (1989) study, for example, viewed their occupation as merely an extension of the traditional feminine role of anticipating male behavior-pleasing and charming men, appearing to be what they want, and following their rules (see also Bradley-Engen 2009). Thus they felt they were really no different from other women who trade their sexuality for financial security in the form of marriage. Other women felt that stripping is beneficial to society in general, as without strip shows, they rationalized, men would be lonely, frustrated, and lacking a sex outlet, and therefore more likely to commit sex crimes (Salutin 1977; Scott 1996; Thompson and Harred 1992). Women also defined 
their work as educational for women in the audience, by showing them how to be sexy, seductive, and comfortable with their bodies, or as having the same entertainment value for society as other types of show business (Salutin 1977; Scott 1996; Skipper and McCaghy 1978).

Strippers are also likely to make use of techniques of neutralization (Sykes and Matza 1957). Sykes and Matza found that five major types of rationalizations protect the individual from self-blame and stigmatization from others: denial of responsibility, denial of injury, denial of the victim, condemnation of the condemners, and appeals to higher loyalties. These techniques appear to be quite common among strippers. As one example, Thompson and Harred (1992; also Thompson, Harred, and Burks 2003) find that strippers make use of each of these techniques in their interactions with others or in their own personal reflections on stripping for a living. They make claims that rationalize their behavior: "Not only is stripping harmless, but it serves positive societal functions" (denial of injury); "we're more honest than those hypocrites who marry for money" (condemnation of the condemners); and "I strip for the money so I can support my daughter" (appeal to higher loyalties).

Finally, many studies highlight how strippers divide their social world into two or more groups. Goffman (1963) argued this to be a central strategy used by individuals to overcome stigma: one group is told nothing of his or her deviant behavior, while the other group(s) is told everything. The strippers in Thompson and Harred's (1992; also Thompson et al. 2003) study, for example, kept their occupation a secret from family, casual acquaintances, and other people they did not know well. Women also sometimes divide their social world by altering their appearance and demeanor, looking and acting like a different person while onstage (Scott 1996; Skipper and McCaghy 1978; Thompson et al. 2003).

These strategies of stigma management, however, can come at a great cost to the individual. "Passers," for example, who pretend to be someone they are not by covering and keeping secrets, can exhibit high levels of alienation, as they are unable to fully identify with those around them (Goffman 1963). Likewise, it obviously requires a great deal of time and energy to effectively hide one part of the self from others. As Goffman (1963) points out, dividing the social world can exact a great psychological cost, in that the lives that the stigmatized work so hard to create and separate are characterized by anxiety, for these constructed realities can collapse at any moment should their impression management techniques fail to protect them. We discuss these and other tolls of stripping in greater detail below.

\section{The Toll of Stripping}

Nearly every study of stripping carries with it descriptions of what Barton (2007) calls the "toll of stripping." This toll is an accumulation of the costs associated with various stigma management techniques, as well as negative experiences related to the day-to-day work in strip clubs (e.g., abuse, harassment, rejection, exhaustion, etc.). Regarding "in-house” tolls, for example, Scott (1996) describes how strippers 
constantly receive, and thus must respond to, "audience abuse," consisting of negative remarks about their bodies, their dance routines, or their reluctance to remove their clothes quickly; Wesely (2006) finds physical and verbal harassment from managers and customers widespread. The physical effects of stripping are clear in BradleyEngen's (2009:32) account of her first night in a new club:

By the end of the night, my left leg was swollen from a pulled hamstring.... My knees were beaten and bruised.... My feet were covered with blisters. My fingernails and toenails were black with filth [from] rolling around on a stage that was covered with sweat, dirt, and body fluids of dozens of other women. My back was killing me from overarching and stimulating sex, and my thighs ached from straddling horny men.... I had been licked, touched, propositioned.

Bradley-Engen was not safe even among the other dancers. At one point that same evening she was kicked in the head by another woman for "not moving fast enough" (p. 33).

Many studies elaborate on the patterns of interaction that take place between strippers and their customers and the strains that result from dancers' emotional labor (Wood 2000). This research suggests that these exchanges are characterized by the "counterfeiting of intimacy" or are "cynical performances" (Enck and Preston 1988; Forsyth and Deshotels 1997; Pasko 2002; Ronai and Ellis 1989; Scott 1996; Thompson et al. 2003). In other words, the interactions between strippers and customers are often illusory, based on inauthentic relationships, and any intimacy expressed is merely a facade. Strippers and customers, these studies argue, have different and conflicting goals. While the customer's goal is to have an intimate or sexual experience of some kind, the stripper's goal is to play off that goal to make money for herself and for the club. The dancer uses both physical and verbal ploys to increase the perception of intimacy. Thompson, Harred, and Burks (2003), among others, argue that this sort of emotional labor, which includes flirting and interacting with customers, many of whom the dancers find "utterly distasteful and even repulsive" (p. 567; see also Barton 2006 and Wood 2000), creates emotional strain and self-conflict for the women, as they continually compromise their attitudes and values to make money.

The toll of stripping also plays out in women's sense of self and personal relationships outside work. The secret-keeping work associated with "dividing the social world" can result in having partially inauthentic exchanges with loved ones as well as customers. Thus strippers often find themselves alienated and estranged from others, impeding their ability, and comfort, in building intimacy or expressing themselves (Philaretou 2006; Thompson et al. 2003).

Research finds that the toll of stripping can also contaminate women's self-esteem and sense of self. Price (2008) finds that many dancers come to internalize the negative stereotypes associated with strippers, and Barton (2007) argues that a dancer's self-esteem is gradually eroded over time, as her self-worth becomes dependent on how much money she makes. Similarly, Wesely (2003) argues that the sexual objectification and fragmentation of dancers' lives, initially employed to reduce the stigma 
associated with stripping, results in identity problems. Women who initially kept strict boundaries regarding physical contact with customers, for example, loosened those boundaries over time, causing them to lose sight of who they felt they really were.

We return to these themes of stigma management and the toll of stripping in our results section, where we consider the question of whether students who strip, through their possession of an alternate, positive identity, might be able to use that identity not only to buffer themselves from some of these negative effects of stripping but also to protect and to enhance their sense of self, both internally and in interaction with others.

\section{DATA AND METHODS}

Our analyses are based on in-depth interviews with college students who work as topless dancers in the Austin, Texas, area. The ten women each work at one of three clubs, which we call the Crystal Fox, Paradise, and Austin All-Stars. These venues represent a specific type of strip club, the more elite, expensive topless bars that cater to business- and middle-class men, often referred to as "gentlemen's clubs" (Bradley-Engen 2009; Trautner 2005). Trautner worked as a cocktail waitress in one club (Austin All-Stars) for about two years.

Trautner interviewed the ten women for this project in the late 1990s. Of these, six are white, three are Latina, and one is Asian American. According to the 2000 U.S. Census, this distribution closely resembles the demographics of Austin's population. It also mirrors those of previous empirical studies of strip clubs and strip-club workers (e.g., Barton 2007; Reid et al. 1994; Ronai and Cross 1998; Ronai and Ellis 1989; Scott 1996; Thompson and Harred 1992; Wesely 2003). While we understand that this is a small sample, making generalizations difficult, we assert that this exploratory study is useful for generating theoretical insights about the experiences of college student strippers. The stories and experiences of these women grant us some leverage in delving further into the identity processes and interactional dynamics of different populations of strippers and stigmatized people.

Trautner began by interviewing three women whom she knew from working at Austin All-Stars and then snowballed an additional four women through those initial three contacts. Three additional women were introduced to her by the general manager of another topless bar. The sample includes eight undergraduates, one graduate student, and one law student. These students have been working as topless dancers from anywhere between six months and six years. We find no noteworthy differences among women based on their length of employment. Table 1 includes basic demographic information for all ten women, including their majors and school and workloads at the time of the interviews. Pseudonyms have been used in place of the respondents' real names, as well as their stage names, throughout the study.

The interviews were based on an open-ended interview guide structured around five broad categories: experiences with school; socialization into the topless bar; navigation of personal, social, and work relationships; management of identities; and plans 


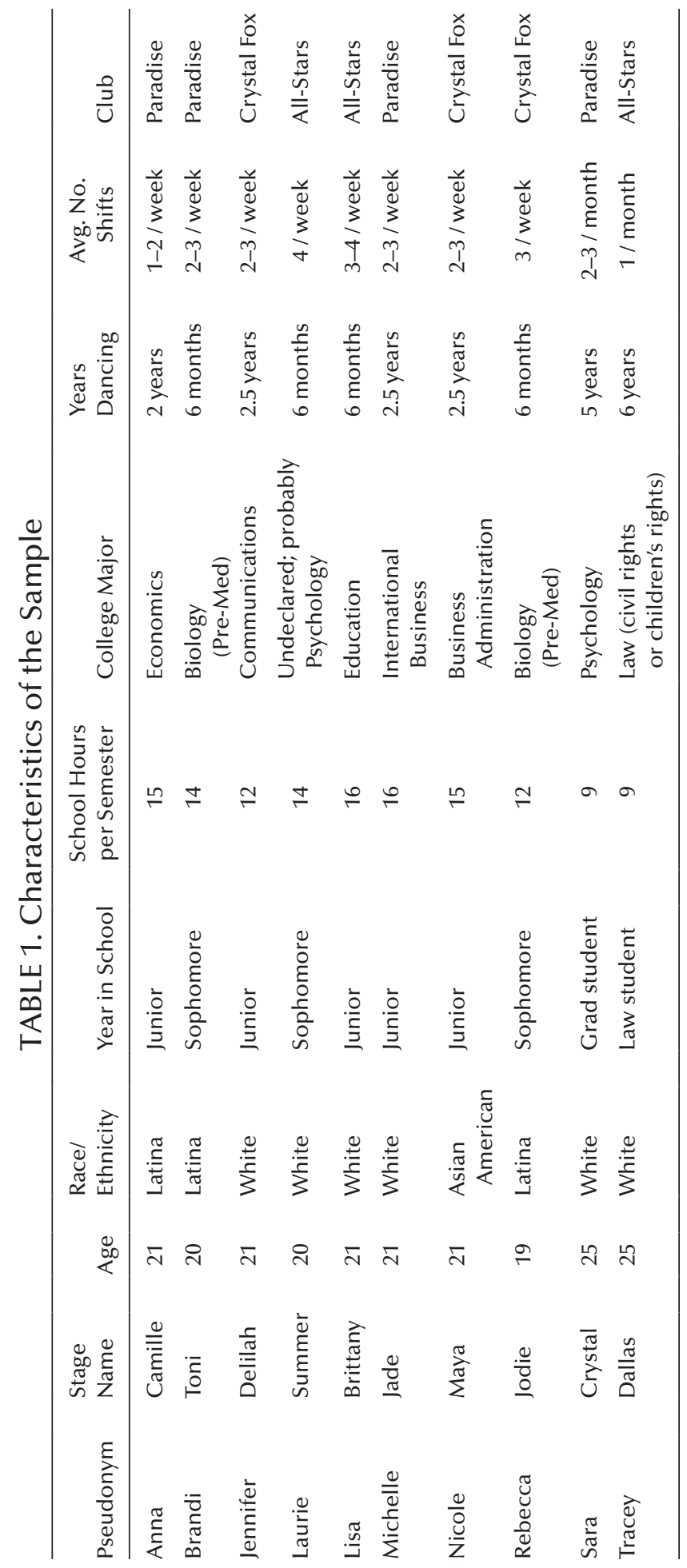


for the future. Although each interview was fairly consistent, the schedule was designed to be flexible in the wording, addition, and deletion of questions and probes.

Both authors analyzed the interview transcripts separately and together for this analysis. Following the "grounded theory" tradition (Glaser and Strauss 1967; Strauss and Corbin 1990), we both read through each interview several times, noting recurring themes. We then developed thematic categories based on the structure of the interview schedule and the literatures on stripping, deviance, and stigmatization. We placed responses from each interview into one or more thematic categories, which we further divided into smaller subgroupings, comparing for similarities and differences. We repeated this process until the analysis was complete.

\section{STRIPPING AWAY THE STIGMA: STUDENT AS A SOCIALLY ACCEPTABLE ALTERNATE IDENTITY}

We separate our results into two general sections that describe the primary strategies women use to negotiate and to manage the stigma associated with their deviant identity (stripper) by engaging their positive identity (student)—internal efforts and interpersonal strategies.

\section{Internal Efforts at Stigma Management: Rejecting Stereotypes and Redefining Selves}

Student strippers employ a number of strategies to reject the stereotypes and stigma associated with strippers. Primary among them is "othering" as a way to differentiate themselves from those stereotypes. As Ronai and Cross (1998) argue, many strippers attempt to distance themselves from other dancers who they feel exemplify the deviance associated with the occupation (the "sleazy" dancer) or who view stripping as a permanent, full-time job (the "immersed" dancer). Dancers draw on these "stereotypical" categories of other dancers to distance themselves from the negative connotations that many people, including some strippers themselves, have of exotic dancers. By showing how they are "not like" stereotypical strippers, the students escape some of the stigma associated with their work. Such "othering" is particularly easy for students who draw on their identities as students as a defining difference.

Sara began stripping thinking that most strippers were "sleazy," into drugs, and generally "going nowhere." Her attitudes about dancers changed a lot over her five years in the occupation, but they ended up confirming her initial ideas:

At first, I thought differently. I thought that it wasn't so much like the stereotype, because I was doing it, and so were a couple of good friends of mine. But the longer I did it, and the more strippers I came into contact with, the overwhelming majority either were that way initially, or they ended up turning out that way because they got so beaten down by what they were doing. It's because the environment doesn't ask anything more of them, and because they have too much time on their hands. They don't do anything with their lives. They don't have any challenges besides trying to look good and have a good body. I'd run into the odd 
person who was not that way, and I'd be friends with them, but they were always just like the exception to the rule. The vast majority really do fit the stereotype. So, I guess that I kind of reverted back to the stereotype, which I'm pretty firmly believing now, because I've seen them and known them for so long.

Sara is thus distancing herself from the stripper stereotype by repeatedly referring to the other strippers she works with as "they" and constructing clear distinctions between her own life choices and the choices of others (Barton 2007). Sara is also actively contrasting others' experiences to her own experience as a student who strips. While she does not mention school explicitly, she implies that there are other important aspects of her life_-goals, commitments, and challenges - that protect her from falling into what she thinks of as stereotypical stripper behavior. While research suggests that strippers across the spectrum participate in othering, students who strip are able to distance themselves not only from other women who strip but also from the generalized stripper identity by assigning that identity to a secondary position in their overall self.

Women reject stripper as a salient identity by drawing on other important identities in forming their selves (Reid et al. 1994; Wesely 2003). This is particularly easy for student strippers, who are able to draw heavily on their positive student identity in constructing the self. For example, Anna and Nicole, like many of the women in our sample, suggested that should future employers inquire about their work history, they would discard the stripper identity entirely and share only that they were students during the time period they stripped. Anna says, "You don't want to get hired for the wrong reasons, and you don't want to chance not getting the job because you tell them that you danced." And, as Nicole points out, "It's not that uncommon for students to not work while they're in school. Well, I'm going to be one of those students who didn't have to work." Other strippers, without an alternate positive identity, would perhaps have a more difficult time accounting for gaps in their résumés.

Many of the women also discussed scheduling their dancing shifts around their studies, highlighting that stripping was neither their primary identity nor their primary priority. Brandi's comments elucidate the rank ordering of these concerns:

I will not work before my tests. ... I had a big chemistry final on Monday and so I just went ahead and [took] the whole weekend off. I was like, "I have to study for the exam." [It] is really more important for me to pass a test than make money.

In a sense, students who strip are able to view stripping as role behavior that supports this positive identity - using the funds for school, working a job with a flexible schedule that allows them to focus on being a student when necessary-rather than as an identity in itself (Turner 1962). In other words, rather than categorize themselves as both strippers and students, these women are able to simply identify as students and to see stripping as part of the repertoire of role expectations associated with that identity. In addition to studying and attending classes, they must work to pay tuition and buy books, and stripping is how they achieve this. As Sara explains,

When school really matters to you, and you have to totally support yourself, something has to give. You can’t be awake twenty-four hours a day. Either you 
have to sacrifice your school and grades so that you can work to support yourself, or you find a job like this one. School is and always has been my top priority. I wasn't going to sacrifice my grades just so that I could work thirty or forty hours a week at some minimum wage job. That's a waste of my time.

Some benefits of being a student who strips are extrinsic, like the flexible schedule or the money it provides. Other benefits are intrinsic. For instance, both Jennifer and Anna believe that dancing has made them more motivated to do well in school. Jennifer says she "now [realizes] how important school is," and Anna reflects,

Dancing has definitely made me more serious about school. I always went to school, but I was one of those people who didn't spend much time studying. I would just hang out, and just briefly look over the notes. I did okay, but now my grades are really, really important to me. I don't want to end up here for the rest of my life. I want to find a good job.

In other words, Anna is stressing that she is not a career dancer, and that she doesn't want to "end up" stripping for the rest of her life. The transient nature of the work for her and other students leads to decreased salience of the stripper identity, particularly with graduation as a benchmark for when the women plan to move on. While we do not have data on whether the students actually stopped at graduation or were lured by the money to continue, we found Michelle's comments future oriented and suggestive of her views of this job as simply a means to an end:

When we all get out into the real world, and start these $\$ 30,000$ jobs, they're going to be happy because then they can actually afford to eat out more than once a month. And me, I'm going to be taking a huge pay cut. So, I'm going to have to approach my first job totally different as far as budgeting. That's why now, I'm selling my car and paying off all my debts. When I graduate, I'm never going to dance again, so I want to make sure that I have as little bills as possible, so that I can afford to take a job that's only $\$ 30,000$.

Michelle, like all nine other interviewees, sees herself stripping as only a shortterm gig to get through school, not a long-term career. This disengagement and the redefinition of the link between identities and role behavior help student strippers experience fewer identity conflicts between their perceived and ideal selves (Peretti and O'Connor 1989).

Previous studies find that while some strippers maintain a "sexy" appearance and continue to wear heavy makeup and provocative clothing outside the strip club (see Wesely 2003), others try to look and act like a different person while not at work (Frank 2002; Scott 1996; Skipper and McCaghy 1978; Thompson et al. 2003). Makeup, costumes, and personality quirks that are part of a stripper's repertoire are separated from her everyday life, and she often takes a stage name to distinguish her everyday self from her stripper persona. Like a child playing dress-up, a stripper uses her costume as a "kind of magical instrument" that allows her to leave her self behind, so to speak, and engage in behavior she sees out of role (Stone 1990:154).

Each woman in our sample created a "dancer persona" (Barton 2006) to help separate her positive identity from her stigmatized one. While tending to dress 
conservatively and wear baggy clothes and little or no makeup while outside the club, all ten women donned a more seductive and risqué appearance while working, activating both an identity and an attitude (Stone 1990). This practice serves important functions. Of course, there is a financial incentive to attend to their appearance for work that does not exist outside the club. But such transformations are internal strategies as well, allowing these women to use their appearance to help keep their identities separate, thus relieving some of their internal self conflicts.

Some of the women, like Laurie, Lisa, Rebecca, and Anna, change their appearance only minimally, simply spending more time on and taking greater care with their makeup and hairstyles. Lisa, for example, says that to get ready for school, "I just roll out of bed and throw on some clothes, and throw my hair up into a ponytail. I don't usually wear makeup, except for lipstick sometimes." While she spends only a few minutes each morning getting ready for school, she uses greater care in getting ready for work. After showering and shaving, Lisa puts on a full face of makeup, curls her hair, and picks out the clothes she is going to wear for the night. Overall, though, her appearance is not dramatically different at work than it is for school. That is, she still looks like Lisa, whether or not she is working.

Other women, however, like Tracey, Nicole, Michelle, and Jennifer, radically alter their self-presentation while at work to separate "stripper" from "student" (Stone 1990). Nicole says that she looks very different at work than she normally does at school. She explains,

\begin{abstract}
When people see me at school, a lot of them think that I am like sixteen years old. I don't wear any makeup at all, I have my hair in a ponytail, and I wear a big T-shirt, big shorts, and flip-flops. I look like a bum when I go to school. I spend a lot of time getting ready for work, though. I fix my hair, wear lots and lots of makeup, and wear sexy, revealing clothing. I probably look about twenty-five or so. It's funny. I never look my age.
\end{abstract}

Similarly, Michelle, Tracey, and Jennifer all said that they didn't wear any makeup, fix their hair, or wear nice clothes to school, but that they were all, as Michelle says, "very picky" about how they looked for work.

As part of this attention to establishing a different appearance, Michelle and Jennifer both say that they will occasionally wear a hairpiece or fake eyelashes to work. Tracey, on the other hand, always wears wigs to work. An aspiring lawyer, Tracey worries that someone she may have professional contact with may recognize her, so she doesn't want to look like Tracey while working. And, she says, "it's kind of fun, like playing dress-up." Because she always wears wigs, she spends a much greater amount of time getting ready for work. She explains,

There's a lot of wig preparation involved. It takes a lot of time to curl hair, sure, a lot of girls do that, but getting a wig on right, so that it will not come off, like when I flip my head or roll over on stage, takes a while. So, I spend a lot of time messing with that, making sure the barrettes fit right and everything, making sure that it looks good, because it's got to look good from every angle, even if I flip my head over. 
Those women who altered their appearances the least with makeup or wigs (Laurie, Lisa, and Anna) were the most adamant about using stage names at work, suggesting that all of the women seek to alter their identity in some way, whether by appearance or by name. These alterations further separate their identities as strippers from those of students.

In addition, by specifically forgoing attention to appearances at school, these strippers are emphasizing their commitment to their student identity. They "dress toward" other students and desire responses that validate their student identities (Stone 1990:149). Nicole explains, "I don't want or need to be attractive at school, because I'm there for one reason, and that's just to go to school. Go to my classes, make good grades, and that's it." She elaborates,

I'm not there for a show. I know there are a lot of girls who get made up for their personal lives. I used to do that, too, before I started dancing. But now, I feel like I just want to get made up for work and that's it. I get so sick of getting made up for work, that during the daytime, I just want to be totally clean and let my skin breathe.

For these women, there is no benefit to constructing sexy, feminine selves at school. At work, the amount of money they make from customers is contingent on how sexy, attractive, and feminine they appear to their male audience (BradleyEngen 2009; Price 1998). At school they want to be recognized for their intelligence and dedication, not their looks.

All ten women created a distinct identity while at work, but their methods differed, as some of the women preferred to use a stage name, while others favored dramatic changes in appearance. By selectively revealing and concealing information about themselves, these women control as much as possible the impressions that others have of them. Moreover, this information control allows these women to manage the stigma of being a topless dancer and further enhances the separateness of their identities. These methods of information control closely resemble the stigma management techniques outlined by Goffman (1963), Thompson and Harred (1992), Scott (1996), and Ronai and Cross (1998). The women in our sample are highly aware of their "discreditable" stigma and so practice narrative resistance in the form of separating themselves from other dancers, dividing the social world by living separate lives for school and work, and actively guarding against getting "caught in the act" (Goffman 1963).

\section{Interpersonal Strategies: Dividing Social Worlds}

In addition to the internal distinctions strippers construct between self and stereotypes or between identities to reduce incongruence in their selves, students who strip draw interpersonal boundaries as well (Barton 2007; Philaretou 2006). One primary way they do this is by "dividing their social worlds" (Goffman 1963), that is, separating their personal and professional lives. They do this by keeping their profession secret from family, professors, and other students, and by not making friends with dancers or customers at work. 


\section{Family}

Not sharing their occupation with their parents lets them be a stripper sometimes and a daughter other times, rather than "our daughter, the stripper." Lisa, like other women in our sample, keeps stripping a secret because she wants to protect her parents from disappointment:

They'd probably like to see me doing something better than taking off my clothes for people. I can imagine having a kid-I probably wouldn't want them showing their body off to a bunch of people. That's why I don't tell them.

Lisa is concerned about letting her parents down, and Michelle keeps dancing secret from her mother because she fears her mother would think less of her or worry. She says, "I don't want her to have bad thoughts about me. I hate lying to her, but I just don't want her to needlessly worry, because she would." Still others keep their work as strippers secret from their parents to limit or to avoid conflict. Laurie says, "I don't want my parents to find out. I think that [it] would really upset my mom and ... I don't want to have to deal with that." Similarly, Rebecca worries that her father might cause a scene and disrupt her life entirely if he were to find out:

My dad would probably come up here and take me back to El Paso.... I wouldn't doubt it if he would disown me like, "I don't ever want to talk to you again if you are going to be in that scene" or whatever.

When asked how she would prepare for an upcoming visit from her parents, who believe she is still waitressing at a local restaurant, Rebecca was still devising a plan: "I guess I am just going to ... [throw] some aprons [and cocktail napkins around my apartment] and say [that] I asked for the week off or something."

\section{Classmates}

Many of the women also worry about people from school finding out about their occupation, because of the potential embarrassment and rumors that could be spread. Jennifer, for example, explains how she handles potential confrontations:

I have seen a couple of guys that went to my school in there, and I didn't really want to have to deal with that, so I just kept my clothes on and hung out in the dressing room until they left. I don't want people to see me almost naked and then run into them at school the next day. I can't imagine trying to act normal after that.

For Jennifer, these situations have financial as well as emotional costs. Not only does she lose money by just "hanging out" in the dressing room (which could be hours), she loses the control she had established of her separate identities when her boundaries became blurred.

Similarly, Brandi does not want anyone at her school finding out because she worries how they will think of her. She explains,

I don't want anyone on campus to know that I do this because I want them to respect me as a student. I don't want them to have a different attitude about me 
once they find out I'm a dancer. I would rather them know me as Brandi the student rather than Brandi the dancer.

Beyond expressing the fear of being "discovered," Brandi's comments illustrate the distinction student strippers made between their student and stripper identities as they engage in role compartmentalization (Turner 1978).

The fears expressed by these women became a reality for Nicole a few months after she began dancing. She had been attending a small, private liberal arts college in another city and was a member of a campus sorority when she ran into three of her professors at work. "They were just as embarrassed as I was," she says. "It was kind of like, I saw you, and you saw me, it's okay, but let's just keep this quiet." This left Nicole feeling pretty uncomfortable, but she felt that the situation was bearable, until the entire football team showed up at the strip club for an aftergame celebration. She says,

I was so embarrassed, but there was nothing I could do. I was onstage. I was totally ostracized by everyone after that. When the girls on my sorority found out, they didn't kick me out, but they really shunned me and called me names like "slut" and "whore." And the guys, well, they just all figured that they could all score with me because I was a dancer.

Nicole ended up transferring to a larger public school in another city because the situation had become intolerable for her. For these women, the sustainment of different selves can be easily managed only when there is a clear segregation of their separate lives. Nicole's story shows how fragile these identity negotiations can be because these identities, and these audiences, can never be completely separated. Some things are beyond an individual's control: family, friends, students, or professors can enter the club at any time; boundaries dividing social worlds can easily and quickly crumble (Goffman 1963).

\section{Significant Others}

There are some people, however, who see these women as both students and strippers-their significant others. Unfortunately, beyond the difficulties this poses for women who seek to separate these spheres to reduce identity contamination, heterosexual relationships between strippers and their partners are often wrought with conflict. Previous research (Philaretou 2006) suggests that conflicts occur in part because boyfriends and husbands are jealous of their partners' stripping or concerned about their work conditions. Rebecca says,

At first he was for it. He was like, "Go ahead, try it out." And then I actually started doing it, you know, and then he would question me like, "Who do you dance for?" You know, like "how many guys do you meet?" And "why do you come home with phone numbers?" And he wanted me to stop dancing.

However, in addition to these types of concerns, we found that partners appeared to also be concerned about people's impressions of them because of the work that 
their girlfriends did. In other words, many men wanted to avoid stigma by association. Michelle says,

[My fiancé] has a problem with people knowing what I do, especially people that he works with. Which I can understand. 'Cause, you know, they're his colleagues and everything, and you don't want them to think that "Oh, well, he's got a stripper slut for a girlfriend," or whatever their misconceptions might be.

Anna's boyfriend expressed similar concerns to her over what his coworkers might think of him based on her working as a stripper:

[When I first started] I felt like he enjoyed it—because maybe it made him look like a hot shot, like his girlfriend was a stripper, you know.... But now it is to the point where he is very paranoid about it. He is very, very paranoid about having someone that he works with come in over there, his VP or anybody. He is very paranoid, and he doesn't want me dancing anymore.

These women, and their partners, believe that a man will be evaluated on the actions and appearances of his significant other (Gillespie 1980). These apprehensions cause conflict in relationships. As Anna says later, "It is a strain on the relationship for sure."

\section{Coworkers and Customers}

Of course coworkers and customers are also aware of the strippers' engagement in "dirty work" (Hughes 1951). To separate stripping from their personal life, most strippers avoid making friends at work. Thus stripping becomes something that women do, not who they are. Both customers and other strippers tend to understand the impersonal nature of the occupation and accept "the nature and structure of involved transactions" (Sweet and Tewksbury 2000b:326). For example, Jennifer says,

I don't really talk to many people while I'm at work. I just kind of take care of my business. I'm friendly with everyone.... I just don't talk to them or hang out with them much at work. I don't call them or go out with them or anything like that.

Likewise, when explaining why she does not hang out with people from the club outside work, Anna draws a distinct boundary: "I am just not trying to go in [the club] to make friends. I am going in there to work," she says. With identity commitment (Stryker and Serpe 1982) often being linked to the quality and quantity of social ties attached to that identity, estrangement from coworkers and customers is another way to decrease the salience of that identity. Being busy with classes and schoolwork, or assuming that others would not be interested in forging connections, protects students from making social ties.

While establishing a "dancer persona" (Barton 2006) may be an internal effort, Laurie explains how she uses her stage name, Summer, to manage interpersonal interactions:

I could use my real name if I wanted to, but I don't. When I go out, I don't want people to say "Hey, Laurie," because I would turn around, thinking they're one of my friends. So if people recognize me and say hello to Summer, then I know 
they're from the club. I use that as kind of a discrepancy when I see people out because I know a lot of people and I can't always remember why I know them. If they know my real name, then they're my friends ... but if they use my stage name, then I know they're from work, so I'll be kind of cautious with them.

Laurie uses the names people use to address her to define the situation, establishing a working consensus of what is occurring and the part that she should play (Goffman 1959; Thomas 1923).

While women tend to be guarded in interactions with coworkers and customers alike, and work diligently to keep their work lives separate from their personal and college lives, they were more than happy to share their student identity with customers and club managers. They often make it a point to tell people at work that they are in college. The women believe that revealing this information upgrades their status within the club, sets them apart from other dancers, and lets the customers know that they are educated women, not just strippers. It also reinforces to themselves and others the fact that this is a temporary job, a means to an end.

Several of the women mentioned that because they are students, management often gives them more leeway with their schedules and allows them other special perks not afforded to other dancers. Anna, for example, says that while most of the women she works with support her going to school, "some of them get kind of aggravated because we [students] don't work on a regular basis." Several of the women believed that going to school is something the clubs would like to promote. One club, for example, ran a program for several years in which the club paid tuition for full-time college students attending public universities who worked at least three shifts a week and maintained a B average in school. (That program has since been disbanded because of the cost of sending so many women through school.) Tracey believes that the clubs have favorable views toward students because, "I think they would like to see dancers and people getting on with their lives and doing something instead of just making money and spending it as quickly as possible." Because these women might attract and entertain a higher class of customers than can some other dancers, the women interviewed perceived college students to have a privileged, elevated status within the club.

Moreover, Tracey's comments suggest that not only are students who strip setting themselves apart from other dancers to make more money and to receive favors from management, they are also escaping the negative identity label applied to other dancers. This is a form of narrative resistance discussed by Ronai and Cross (1998). Dancers who are not in school, and who act "super flirty" with customers, are the negative standards of comparison that the women in our sample resist. As illustrated earlier, several dancers did not reject the deviant stigma others apply to the occupation as a whole, but they distanced themselves from that label by showing how they "are not like" the deviant exemplars.

Students who strip believe that this distancing work is authentic and effortless. Jennifer expressed that she did not have to resort to the same manipulation tactics as "other" dancers because she "respects herself," and customers sense that. She explains, 
I tell customers that I'm a student. I think that they're kind of surprised, because I guess a lot of them don't think that many of us go to school. They like it, they think it's really good that I'm in school. And I don't act like those other girls. I don't go overboard. I don't act like I'm real attracted to them, like I think they're sexy and all that. And they can see that I'm more real and down to earth. Other girls use those tactics, like giving them back massages and acting super flirty. But I just act normal and carry on a normal conversation. I don't act like a slut just because I'm working there, like a lot of the girls do.

Tracey says that her customers "definitely like it, that I'm smart and doing something, because I don't have a sob story. I don't go up to them up say things like, 'Omigosh, I can't feed my children.' And there are so many girls that do that."

This is not to say that there is no manipulation among students who strip. Michelle reveals her status as a student to customers because she believes this information increases her tips. She explains that although her parents are paying both her rent and tuition, customers often think that she is stripping as a way to pay for school: "My customers think it's great that there's a purpose for me doing it, so they feel a little better about giving me money because they think it's going to my college fund."

Several women related similar stories of being paid for their conversation and personality, not just their attractiveness. Brandi, for example, believes that because of her education and interest in science, many customers pay her just for talking to them:

There is this huge group of guys that come in pretty regularly, and they're working on some computer thing. They all have physics degrees, chemistry degrees, and biology degrees, and they just sit down and talk to me about science. And we will sit there for hours, talking about science, and they just hand me all of this money.

These stories further separate these women from the other dancers who are not in school, as well as from the larger pool of sex workers who are often thought to engage in emotionally draining "strategic flirting" and play dumb around men (Dean et al. 1975; Deshotels and Forsyth 2006).

While being in school affords these women positive relationships with customers and management, Nicole and Anna mentioned that their status as students has caused some minor problems with other dancers. As Anna said previously, a few dancers she works with get aggravated because she does not have to work regularly and because they think the manager does small favors for her. Nicole says that some of the dancers she works with think that she is a narc, an informant for law enforcement or management:

Everybody has heard the rumors. It's because I'm very educated compared to those girls, and because of my mannerisms. I was brought up in a very upper-middle-class household, and I just learned how to do things properly. So they think that because I'm educated and that I'm in school, that I'm a narc. Some of the girls that I've worked with for a really long time have even asked me if I was a spy.

Both Anna and Nicole stress that most of the dancers they work with are supportive of their schoolwork, but that a few of them do not like the student strippers getting special attention. 


\section{CONCLUSIONS}

While no one is immune to every harmful effect of having a deviant identity, in this article we argue that students who strip occupy a unique position that offers them some respite from the potential negative effects of stripping. We find that students who strip are distinctive from other strippers in several ways. First, they benefit from having alternate identities from which to choose self-definitions, specifically their salient positive identity as students. Second, because they are students, they are likely to think of themselves as "transient" rather than "career" strippers (Philaretou 2006). They view stripping as a means to an end, supporting the important goal of obtaining a degree, rather than the end in itself. With research suggesting that the negative effects of stripping increase over time spent working in clubs (Peretti and O'Connor 1989), true transience is important for preserving a positive sense of self. Third, although they often feel as if they live a "double-life" (Lewin 1984), hiding their occupation from family, friends, and those at school, students who strip are able to share with customers their aspirations as students, further differentiating them from other strippers. Having an identity other than stripper, particularly a positive one like college student, which they draw on in social interactions both in and out of the club, allows these women to maintain a positive sense of self.

In large part, students who strip benefit from the contextual nature of stigma. Their behavior at the club, while largely indistinguishable from the nonstudents, is experienced in a notably different way. In their discussion of the relational nature of stigma, Jones and colleagues (1984) outline six dimensions of stigma: concealability (the viability of the stigmatizing characteristic), peril (the perceived danger to others), origin (e.g., congenital, accidental, or intentional), course of the mark (whether the characteristic gets more pronounced with time), aesthetics (subjective reactions to the stigma's unattractiveness), and disruptiveness (the extent to which the stigma interferes with interactions and social life). All strippers benefit from having a concealable stigma, which poses little or no danger to others. However, students who strip benefit markedly in the other dimensions as well. Students who strip can alleviate some of the stigma from intentionality of their occupation by rationalizing their work. Whether or not they rely on their earnings for tuition, these women believe that stripping is supporting a series of positive life choices they have been making, rather than stripping as a result of what they see as negative life choices of "other" dancers (e.g., women who dropped out of school, women who had children at a young age, women who use drugs). Further, the shortened tenure of transient strippers also lessens stigma by not giving the stigma time to become more pronounced and helping them focus on the allure and attractiveness of being women who strip occasionally. Finally, the ability to draw on other identities - specifically the positive student identity-and to hide their deviant identity from people whom they interact with in other spheres allows the college students who strip to limit the disruptiveness of that work in their everyday lives.

Of course, distinctive spheres and keeping secrets can have negative effects as well. Strippers in general have considerable difficulty in attaining and maintaining genuine, meaningful, and anxiety-free intimate interactions with significant others (Philaretou 
2006) and are often withdrawn from people in general (Peretti and O'Connor 1989). Because student strippers are dividing their social world in ways that involve keeping secrets from their family members, classmates, professors, casual acquaintances, and keeping information from friends and romantic partners, they may end up feeling particularly alienated or estranged. Engaging in so many partially inauthentic interactions outside work can impede their ability and comfort in building intimacy with others or expressing themselves.

While this alienation and estrangement might be issues many strippers share, the results of our exploratory study suggest that there are many important differences within the social category of strippers that should receive further attention. We substantiate this claim by exploring the unique experiences of students who strip and find that they benefit from this alternate identity and the dynamic constructions of both stigma and self-esteem. In addition, we suggest useful theoretical avenues to pursue in attending to this variation-specifically social psychological work on identity, stigma, and self-perception.

We see contributions of this work to both bodies of research. To the interactionists, we bring stigma management processes out of the laboratory and explore how truly stigmatized people negotiate and manage their stigma to preserve their sense of self. While ours is not truly an "interactional" study (Hebl and Dovidio 2005), hopefully future research, perhaps by sociologists and symbolic interactionists, will follow suit and consider the nuances of stigma in "real life" situations. We hope our research also captures the attention of those who study stripping and other sex-work occupations and encourages them to look for important differences among individuals and groups of individuals who work in these occupations.

Acknowledgments: Mary Nell Trautner collected the data for this article for her undergraduate honors thesis; all other contributions of the two authors are equal. The authors wish to thank Maria Lowe, Edward Kain, Dan Hilliard, and Shannon Winnubst for comments on early drafts.

\section{REFERENCES}

Allon, Natalie. 1982. "The Stigma of Overweight in Everyday Life." Pp. 130-74 in Psychological Aspects of Obesity: A Handbook, edited by B. Wolman. New York: Van Nostrand-Reinhold.

Allport, Gordon W. 1954. The Nature of Prejudice. Cambridge, MA: Addison-Wesley.

Archer, Dane. 1985. "Social Deviance." Pp. 743-804 in The Handbook of Social Psychology, edited by G. Lindzey and E. Aronson. New York: Random House.

Barton, Bernadette. 2006. Stripped: Inside the Lives of Exotic Dancers. New York: New York University Press.

. 2007. "Managing the Toll of Stripping: Boundary Setting among Exotic Dancers." Journal of Contemporary Ethnography 36(5):571-96.

Bradley, Mindy S. 2008. "Stripping in the New Millennium: Thinking about Trends in Exotic Dance and Dancers' Lives.” Sociology Compass 2(2):503-18.

Bradley-Engen, Mindy S. 2009. Naked Lives: Inside the Worlds of Exotic Dance. Albany: State University of New York Press. 
Branscombe, Nyla R., Michael T. Schmitt, and Richard D. Harvey. 1999. "Perceiving Pervasive Discrimination among African Americans: Implications for Group Identification and WellBeing." Journal of Personality and Social Psychology 77(1):135-49.

Brewer, Marilynn B. 1991. "The Social Self: On Being the Same and Different at the Same Time." Personality and Social Psychology Bulletin 17(5):475-82.

Cooley, Charles H. 1902. Human Nature and the Social Order. New York: Scribner's.

Crandall, Christian S. 1994. "Prejudice against Fat People: Ideology and Self-Interest?" Journal of Personality and Social Psychology 66(5):882-94.

Crocker, Jennifer. 1999. "Social Stigma and Self-Esteem: Situational Construction of Self- orth." Journal of Experimental Social Psychology 35(1):87-107.

Crocker, Jennifer and Brenda Major. 1989. "Social Stigma and Self-Esteem: The Self-Protective Properties of Stigma." Psychological Review 96(4):608-30.

Crocker, Jennifer and Diane M. Quinn. 2001. "Psychological Consequences of Devalued Identities." Pp. 238-59 in Blackwell Handbook of Social Psychology: Intergroup Processes, edited by R. Brown and S. Gaertner. Malden, MA: Blackwell-Wiley.

Dean, Dwight G., Edward A. Powers, Rita Braito, and Brent Bruton. 1975. "Cultural Contradictions and Sex Roles Revisited: A Replication and a Reassessment.” Sociological Quarterly 16(2):207-15.

Deshotels, Tina and Craig J. Forsyth. 2006. "Strategic Flirting and the Emotional Tab of Exotic Dancing." Deviant Behavior 27(2):223-41.

Downs, Daniel M., Shaan James, and Gloria Cowan. 2006. "Body Objectification, Self-Esteem, and Relationship Satisfaction: A Comparison of Exotic Dancers and College Women." Sex Roles 54:745-52.

Enck, Graves E. and James D. Preston. 1988. "Counterfeit Intimacy: A Dramaturgical Analysis of an Erotic Performance." Deviant Behavior 9(4):369-81.

Forsyth, Craig J. and Tina H. Deshotels. 1997. "The Occupational Milieu of the Nude Dancer." Deviant Behavior 18(2):125-42.

Frank, Katherine. 2002. G-Strings and Sympathy: Strip Club Regulars and Male Desire. Durham, NC: Duke University Press. .2007. “Thinking Critically about Strip Club Research.” Sexualities 10(4):501-17.

Gillespie, Joanna. 1980. "The Phenomenon of the Public Wife: An Exercise in Goffman's Impression Management." Symbolic Interaction 3(2):109-26.

Glaser, Barney G. and Anselm L. Strauss. 1967. The Discovery of Grounded Theory: Strategies for Qualitative Research. Chicago: Aldine.

Goffman, Erving. 1959. The Presentation of Self in Everyday Life. New York: Doubleday. 1963. Stigma: Notes on the Management of Spoiled Identity. New York: Simon and Schuster.

Hebl, Michelle R. and John F. Dovidio. 2005. "Promoting the 'Social' in the Examination of Social Stigmas." Personality and Social Psychology Review 9(2):156-82.

Hughes, Everett C. 1951. "Work and the Self." Pp. 313-23 in Social Psychology at the Crossroads, edited by J. H. Rohrer and M. Sherif. New York: Harper and Brothers.

Jones, Edward E., Amerigo Farina, Albert H. Hastorf, Hazel Markus, Dale T. Miller, and Robert Scott. 1984. Social Stigma: The Psychology of Marked Relationships. New York: Freeman.

Lewin, Laurie. 1984. Naked Is the Best Disguise: My Life as a Stripper. New York: William and Morrow.

Lewis, Jacqueline. 2000. “Controlling Lap Dancing: Law, Morality, and Sex Work.” Pp. 203-16 in Sex for Sale: Prostitution, Pornography, and the Sex Industry, edited by R. Weitzer. New York: Routledge.

Major, Brenda N. and Laurie T. O’Brien. 2005. “The Social Psychology of Stigma.” Annual Review of Psychology 56:393-421.

Mead, George H. 1934. Mind, Self, and Society. Chicago: University of Chicago Press.

Miller, Carol T. and Brenda Major. 2000. "Coping with Stigma and Prejudice." Pp. 243-71 in The Social Psychology of Stigma, edited by T. F. Heatherton, R. E. Kleck, M. R. Hebl, and J. G. Hull. New York: Guilford. 
Pasko, Lisa. 2002. “Naked Power: Stripping as a Confidence Game.” Sexualities 5(1):49-66.

Peretti, Peter O. and Patrick O'Connor. 1989. "Effects of Incongruence between the Perceived Self and the Ideal Self on Emotional Stability of Strippers." Social Behaviour and Personality 17(1):81-92.

Philaretou, Andreas G. 2006. "Female Exotic Dancers: Intrapersonal and Interpersonal Perspectives." Sexual Addiction and Compulsivity 13(1):41-52.

Price, Kim. 1998. "Stripping Work: Women's Labor Power in Strip Clubs." Paper presented at the American Sociological Association meeting, San Francisco, August 21.

.2008. “'Keeping the Dancers in Check': The Gendered Organization of Stripping Work in the Lion's Den." Gender \& Society 22(3):367-89.

Quinn, Diane M. and Jennifer Crocker. 1999."When Ideology Hurts: Effects of Belief in the Protestant Ethic and Feeling Overweight on the Psychological Well-Being of Women.” Journal of Personality and Social Psychology 77(2):402-14.

Reid, Scott A., Jonathon A. Epstein, and D. E. Benson. 1994. "Role Identity in a Devalued Occupation: The Case of Female Exotic Dancers." Sociological Focus 27(1):1-27.

Ronai, Carol Rambo and Rabecca Cross. 1998. "Dancing with Identity: Narrative Resistance of Male and Female Stripteasers." Deviant Behavior 19(2):99-119.

Ronai, Carol Rambo and Carolyn Ellis. 1989. "Turn-Ons for Money: Interactional Strategies of the Table Dancer." Journal of Contemporary Ethnography 18(3):271-98.

Salutin, Marilyn. 1977. "Stripper Morality.” Pp. 191-208 in Deviant Life-Styles, edited by J. Henslin. New Brunswick, NJ: Transaction Books.

Schmader, Toni, Brenda Major, Collette P. Eccleston, and Shannon K. McCoy. 2001. "Devaluing Domains in Response to Threatening Intergroup Comparisons: Perceived Legitimacy and the Status Value Asymmetry. Journal of Personality and Social Psychology 80(5):782-96.

Scott, David A. 1996. Behind the G-String: An Exploration of the Stripper's Image, Her Person, and Her Meaning. Jefferson, NC: McFarland.

Skipper, James K. and Charles H. McCaghy. 1978. "Teasing, Flashing, and Visual Sex: Stripping for a Living." Pp. 171-93 in The Sociology of Sex: An Introductory Reader, edited by J. M. Henslin and E. Sagarin. New York: Schocken Books.

Sloan, Lacey and Stéphanie Wahab. 2004. "Four Categories of Women Who Work as Topless Dancers." Sexuality and Culture 8(1):18-43.

Stone, Gregory P. 1990. "Appearance and the Self: A Slightly Revised Version.” Pp. 141-62 in Life as Theater: A Dramaturgical Sourcebook, 2nd ed., edited by D. Brissett and C. Edgley. New York: Aldine.

Strauss, Anselm and Juliet Corbin. 1990. Basics of Qualitative Research: Grounded Theory Procedures and Techniques. Newbury Park, CA: Sage.

Stryker, Sheldon and Richard T. Serpe. 1982. "Commitment, Identity Salience, and Role Behavior: A Theory and Research Example.” Pp. 199-218 in Personality, Roles, and Social Behavior, edited by W. Ickes and E. S. Knowles. New York: Springer-Verlag.

Sweet, Nova and Richard Tewksbury. 2000a. "Entry, Maintenance and Departure from a Career in the Sex Industry: Strippers' Experiences of Occupational Costs and Rewards." Humanity and Society 24(2):136-61. .2000b. "'What's a Nice Girl Like You Doing in a Place Like This?': Pathways to a Career in Stripping." Sociological Spectrum 20(3):325-43.

Sykes, Gresham M. and David Matza. 1957. "Techniques of Neutralization: A Theory of Delinquency." American Sociological Review 22(6):664-70.

Thomas, William I. 1923. The Unadjusted Girl: With Cases and Standpoint for Behavior Analysis. Boston: Little, Brown.

Thompson, William E. and Jackie L. Harred. 1992. "Topless Dancers: Managing Stigma in a Deviant Occupation." Deviant Behavior 13(3):291-311.

Thompson, William E., Jackie L. Harred, and Barbara E. Burks. 2003. "Managing the Stigma of Topless Dancing: A Decade Later." Deviant Behavior 24(6):551-70. 
Trautner, Mary Nell. 2005. "Doing Gender, Doing Class: The Performance of Sexuality in Exotic Dance Clubs." Gender \& Society 19(6):771-88.

Turner, Ralph H. 1962. "Role Taking: Process versus Conformity." Pp. 20-39 in Human Behavior and Social Processes, edited by A. Rose. Boston: Houghton Mifflin. .1978. "The Role and the Person." American Journal of Sociology 84(1):1-23.

Wesely, Jennifer K. 2003. “'Where Am I Going to Stop?': Exotic Dancing, Fluid Body Boundaries, and Effects on Identity." Deviant Behavior 24:483-503. .2006. "Negotiating Myself: The Impact of Studying Female Exotic Dancers on a Feminist Researcher." Qualitative Inquiry 12(1):146-62.

Wood, Elizabeth Anne. 2000. "Working in the Fantasy Factory." Journal of Contemporary Ethnography 29(1):5-31. 